\title{
The role of morphine in regulation of cancer cell growth
}

\author{
Katarzyna Gach • Anna Wyrębska • Jakub Fichna • \\ Anna Janecka
}

Received: 31 May 2011 / Accepted: 13 July 2011 / Published online: 29 July 2011

(C) The Author(s) 2011. This article is published with open access at Springerlink.com

\begin{abstract}
Morphine is considered the "gold standard" for relieving pain and is currently one of the most effective drugs available clinically for the management of severe pain associated with cancer. In addition to its use in the treatment of pain, morphine appears to be important in the regulation of neoplastic tissue. Although morphine acts directly on the central nervous system to relieve pain, its activities on peripheral tissues are responsible for many of the secondary complications. Therefore, understanding the impact, other than pain control, of morphine on cancer treatment is extremely important. The effect of morphine on tumor growth is still contradictory, as both growth-promoting and growthinhibiting effects have been observed. Accumulating evidence suggests that morphine can affect proliferation and migration of tumor cells as well as angiogenesis. Various signaling pathways have been suggested to be involved in these extraanalgesic effects of morphine. Suppression of immune system by morphine is an additional complication. This review provides an update on the influence of morphine on the growth and migration potential of tumor cells.
\end{abstract}

Keywords Apoptosis · Proliferation · Angiogenesis ·

Migration $\cdot$ Metastasis

$\begin{array}{ll}\text { Abbreviations } \\ \text { BAD } & \text { Bcl- } \mathrm{x}_{\mathrm{L}} / \mathrm{Bcl}-2 \text {-associated death promoter protein } \\ \mathrm{CNS} & \text { Central nervous system } \\ \mathrm{COX}-2 & \text { Cyclooxygenase-2 } \\ \text { ECM } & \text { Extracellular matrix }\end{array}$

K. Gach · A. Wyrębska · J. Fichna $\cdot$ A. Janecka $(\bowtie)$

Department of Biomolecular Chemistry,

Medical University of Lodz,

Mazowiecka 6/8,

92-215 Lodz, Poland

e-mail: anna.janecka@umed.lodz.pl

$\begin{array}{ll}\text { EGF } & \text { Epidermal growth factor } \\ \text { Erk } & \text { Extracellular-regulated kinase } \\ \text { IL } & \text { Interleukin } \\ \text { JNK } & \text { c-Jun N-terminal kinase } \\ \text { MAPK } & \text { Mitogen-activated protein kinase } \\ \text { MMPs } & \text { Matrix metalloproteinases } \\ \text { MNTX } & \text { Methylnaltrexone } \\ \text { NF-kB } & \text { Nuclear factor kB } \\ \text { NO } & \text { Nitric oxide } \\ \text { NOS } & \text { Nitric oxide synthase } \\ \text { PAI-1 } & \text { Plasminogen activator inhibitor-1 } \\ \text { PAI-2 } & \text { Plasminogen activator inhibitor-2 } \\ \text { PGE } 2 & \text { Prostaglandin E } 2 \\ \text { PI3K } & \text { Phosphatidylinositol 3-kinase } \\ \text { RhoA } & \text { Ras homolog gene family, member A } \\ \text { ROS } & \text { Reactive oxygen species } \\ \text { Src } & \text { Non-receptor tyrosine kinase } \\ \text { TIMPs } & \text { Tissue inhibitors of metalloproteinases } \\ \text { TNF } & \text { Tumor necrosis factor } \\ \text { uPA } & \text { Urokinase plasminogen activator } \\ \text { uPAR } & \text { Urokinase plasminogen activator membrane- } \\ \text { VEGF } & \text { linked receptor } \\ & \text { Vascular endothelial growth factor }\end{array}$

\section{Introduction}

Morphine, the main component of opium, is perhaps the oldest drug known to man. Pure morphine was isolated in 1803 by Sertürner (Schmitz 1985), and its structure was elucidated 120 years later. Full systemic name of morphine

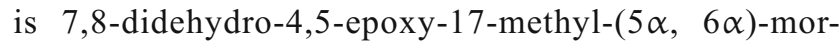
phinan-3,6-diol. Morphine was found to be a particularly good analgesic and sedative, far more effective than crude 
opium. Morphine was shown to exert its action through opioid receptors ( $\mu, \delta$, and $\kappa$ ) localized in the brain (Pasternak 1993; Reisine and Bell 1993; Harrison et al. 1998; Kieffer 1999; Kieffer and Gaveriaux-Ruff 2002). However, morphine binds to the $\mu$-opioid receptor with nearly two orders of magnitude greater affinity compared with the other two opioid receptors (Zadina et al. 1994). Although morphine acts directly on the central nervous system (CNS) to relieve pain, its activity on peripheral tissues is responsible for many of the secondary complications. Besides its strong analgesic effect, morphine exerts a number of adverse side-effects, including addiction, tolerance, respiratory depression, immunosuppression, and constipation. The lack of equally strong painkillers is the reason that despite the drawbacks mentioned above, morphine is still the most commonly used analgesic for management of severe pain, including cancer pain (Mantyh 2006). Administration of morphine to cancer patients gave evidence that apart from its analgesic action, morphine can significantly alter tumor growth. In the last decade, numerous studies employing cancer cell lines and experimental animals have been performed to reveal complex mechanisms by which morphine affects tumor cells. Whereas the pharmacology and function of opioids in the CNS have been extensively characterized, still little is known about their effect on cancer cells. The results obtained so far are conflicting. In the past, morphine was reported to increase the proliferation of endothelial and tumor cells (Simon and Arbo 1986; Moon 1988; Ishikawa et al. 1993; Gupta et al. 2002). On the other hand, morphine and other opioids were also found to promote tumor cell death (Maneckjee et al. 1990; Yeager and Colacchio 1991; Page et al. 1993; Hatzoglou et al. 1996; Sueoka et al. 1996, 1998). Several reviews have covered this important research area from different perspectives (Rasmussen et al. 2002; Fichna and Janecka 2004; Tegeder and Geisslinger 2004; Chen et al. 2008). This review will focus on the latest findings on the influence of morphine on tumor cell proliferation, apoptosis, angiogenesis, and migration.

\section{Effect of morphine on tumor growth}

Despite extensive research, it is still not well understood whether morphine itself directly modifies the growth of tumor cells. Some authors postulate that morphine can promote tumor growth and reduce the survival rate of tumor-bearing animals due to immunosuppression, since the negative effects of morphine and other opioids on the immune system are well established (Odunayo et al. 2010). On the other hand, multiple research data indicate that morphine can accelerate or inhibit cancer cell growth in vitro and in vivo by different mechanisms.
High concentrations of morphine were shown to reduce the growth of tumors. Tegeder et al. (2003) reported that morphine inhibited tumor cell proliferation at concentrations of $>10 \mu \mathrm{M}$. In nude mice, morphine significantly reduced the growth of MCF-7 and MDA-MB-231 tumors. Intermittent injections of morphine decreased the growth of tumors in a rat model of metastasizing colon cancer (Yeager and Colacchio 1991).

On the other hand, morphine was shown to trigger stimulation of human glioblastoma $\mathrm{T} 98 \mathrm{G}$ cell proliferation (Lazarczyk et al. 2010). Gupta et al. (2002) demonstrated that morphine, in clinically relevant doses, promoted tumor neovascularization in a human breast tumor xenograft model in mice, leading to increased tumor progression.

The discrepancies in results may be due to the differences in administered doses or/and the mode of administration (systemic versus localized). These examples, as well as some other reports (Maneckjee et al. 1990; Harimaya et al. 2002; Sasamura et al. 2002), showed that tumor suppression occurs after chronic high doses of morphine, while tumor-enhancing effects with morphine occur after a single dose or low daily doses (Zong and Pollack 2000). This dual concentration-dependent effect, i.e., mitogenesis at low and growth inhibition at higher concentrations was observed both in vitro and in vivo.

The lack of effects of morphine on the proliferation of colon cancer HT-29 cells (Zagon et al. 1996; Nylund et al. 2008) and on breast cancer MCF-7 cells was also reported (Janecka et al. 2004).

Recently, it was demonstrated that the $\mu$-opioid receptor regulates cancer progression in animal models (Moss and Rosow 2008; Wang et al. 2009; Singleton and Moss 2010). The $\mu$-opioid receptor-knockout mice were shown not to develop significant tumors when injected with Lewis lung cancer cells as did the wild-type controls (Mathew et al. 2009). Silencing the expression of the $\mu$-opioid receptor in Lewis lung cancer cells inhibited lung metastasis in wildtype mice by about $75 \%$. Finally, infusion of the $\mu$-opioid receptor antagonist, methylnaltrexone, markedly attenuated tumor growth in wild-type mice treated with Lewis lung cancer cells by up to $90 \%$ (Mathew et al. 2009). These experimental data strongly support the hypothesis that the $\mu$-opioid receptor promotes tumor growth and metastasis.

Possible mechanisms of morphine action mediated through the opioid receptors are demonstrated in Fig. 1 and through the non-opioid pathways in Fig. 2. The summary of in vivo growth-promoting and growthinhibiting effects of morphine is presented in Table 1.

\section{Effect of morphine on tumor apoptosis}

Apoptosis is an active process of controlled cell death in the development and maintenance of tissue homeostasis. 
Fig. 1 Possible mechanisms of opioid receptor mediated influence of morphine on tumor growth. Morphine binds to the $\mu$-opioid receptor and a stimulates MAPK/Erk pathway, which results in the cell cycle progression; $\mathbf{b}$ activates $\mathrm{PI} 3 \mathrm{~K} / \mathrm{Akt}$ pathway mediating antiapoptotic effects; c up-regulates uPA expression and secretion promoting metastasis; $\mathbf{d}$ transactivates VEGF receptors and induces angiogenesis; e suppresses the function of $\mathrm{T}$ lymphocytes, leading to immunosuppression

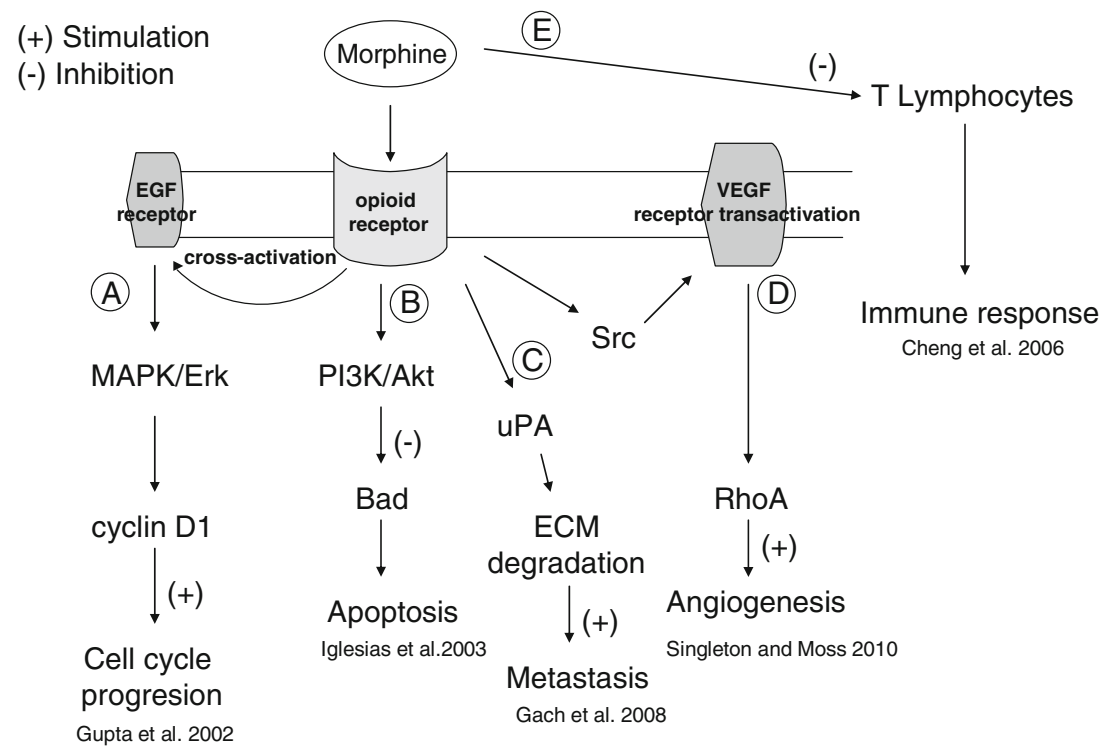

Apoptosis is controlled by two main pathways, the intrinsic or the mitochondrial-mediated pathway (Green and Reed 1998) and the extrinsic or death receptor-mediated pathway (Ashkenazi and Dixit 1999). Mitochondrial-mediated apoptosis is controlled by Bcl-2 family of proteins (Cory and Adams 2002; Cory et al. 2003). The death receptormediated pathway is initiated by the ligation of cell death ligands with their death receptors (Sartorius et al. 2001). Caspase-3 is activated in both apoptotic pathways and plays central role in the execution phase of cell apoptosis (Ashkenazi and Dixit 1999; Hengartner 2000; Fulda and Debatin 2006).
Apoptosis is usually deregulated in cancer cells, and this deregulation can contribute to uncontrollable proliferation and tumor growth (Hanahan and Weinberg 2000; Hengartner 2000; Kaufmann and Hengartner 2001). Morphine was shown to induce the apoptosis of human endothelial cells (Hsiao et al. 2009) and of T lymphocytes and macrophages (Kapasi et al. 2004). Morphine in high concentrations $\left(10^{-3}\right.$ $10^{-6} \mathrm{M}$ ) was demonstrated to induce apoptotic cell death in human tumor cell lines (Kawase et al. 2002; Hatsukari et al. 2003). In other studies, the pro-apoptotic effect of morphine in human tumor cell lines was observed at clinical concentration $\left(10^{-8} \mathrm{M}\right)$ (Smith et al. 1999; Hatsukari et al.
Fig. 2 Possible pathways, other than through the opioid receptors, by which morphine influences cancer progression and suppression

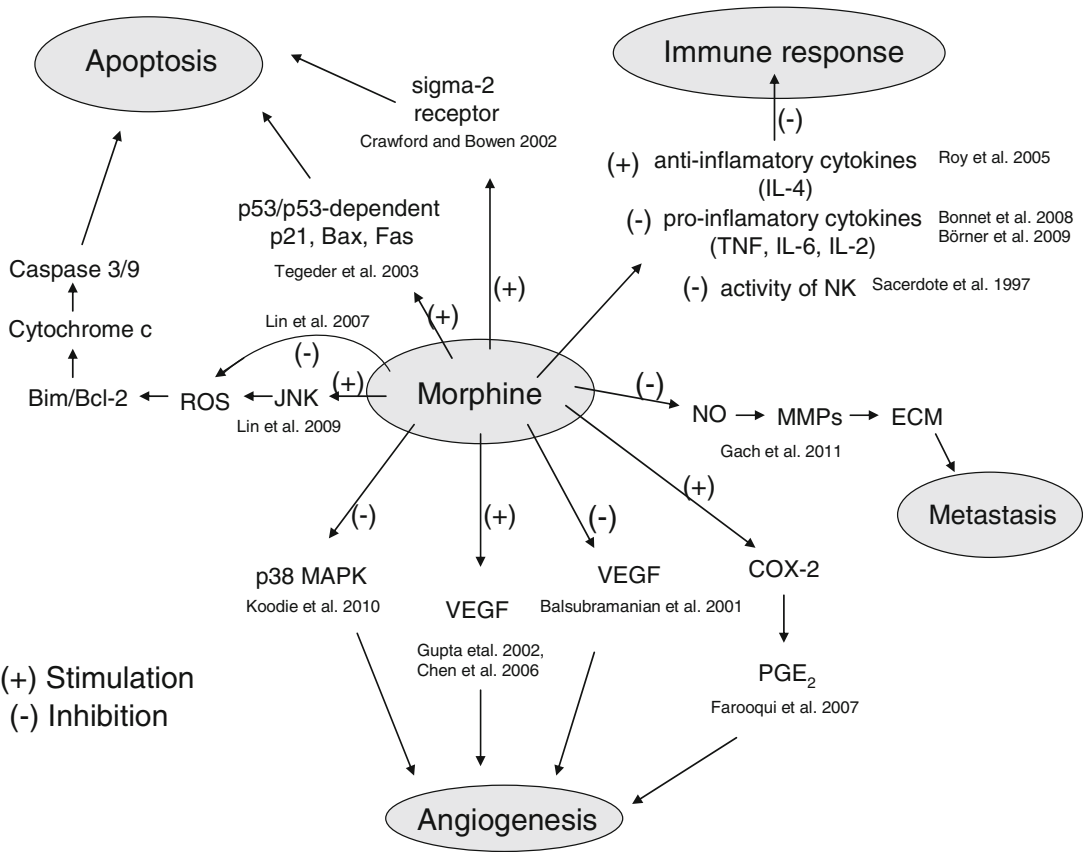


Table 1 Summary of in vivo growth-promoting and growth-inhibiting effects of morphine

\begin{tabular}{|c|c|c|c|c|c|}
\hline $\begin{array}{l}\text { Cell line/tumor } \\
\text { type }\end{array}$ & In vivo effects & In vivo dose/time & Suggested mechanism & Antagonist/inhibition & Ref. \\
\hline $\begin{array}{l}\text { Ehrlich } \\
\text { carcinoma } \\
\text { injected s.c. in } \\
\text { the left thigh of } \\
\text { BALB/c mice }\end{array}$ & $\begin{array}{r}\text { Stimulation of } \\
\text { angiogenesis }\end{array}$ & $\begin{array}{l}0.714 \mathrm{mg} / \mathrm{kg} / \text { day for } \\
7 \text { days (equivalent to } \\
50 \mathrm{mg} \text { per day for a } \\
70 \mathrm{~kg} \text { human) }\end{array}$ & & & $\begin{array}{l}\text { Ustun et al. } \\
2010\end{array}$ \\
\hline $\begin{array}{l}\text { Colon cancer } \\
\text { cells injected i. } \\
\text { p. in Fisher } 344 \\
\text { rats }\end{array}$ & $\begin{array}{l}\text { Inhibition of tumor } \\
\text { growth and metastasis } \\
\text { (significant decrease } \\
\text { in the hepatic tumor } \\
\text { burden) }\end{array}$ & $\begin{array}{l}20 \mathrm{mg} / \mathrm{kg} / \text { day s.c., the } \\
\text { day before and for } \\
2 \text { days after colon } \\
\text { cancer cell inoculation }\end{array}$ & $\begin{array}{l}\text { Enhancement of NK cell } \\
\text { activity at the time of } \\
\text { tumor cell injection }\end{array}$ & & $\begin{array}{l}\text { Yeager and } \\
\text { Colacchio } \\
1991\end{array}$ \\
\hline $\begin{array}{l}\text { MCF-7, MDA- } \\
\text { MB231 breast } \\
\text { cancer or HT- } \\
29 \text { colon cancer } \\
\text { cells injected s. } \\
\text { c. in NMRI-nu/ } \\
\text { nu mice }\end{array}$ & $\begin{array}{l}\text { Inhibition of tumor } \\
\text { growth (MCF-7 and } \\
\text { MDA-MB231) no ef- } \\
\text { fect on HT-29 tumors }\end{array}$ & $\begin{array}{l}10-30 \mathrm{mg} / \mathrm{kg} / \text { day i.p. for } \\
3 \text { weeks (stepwise } 10, \\
20, \text { and } 30 \mathrm{mg} / \mathrm{kg} \text { / } \\
\text { day i.p. for the first, } \\
\text { second, and third week) }\end{array}$ & $\begin{array}{l}\text { Inhibition of tumor } \\
\text { growth through a p53 } \\
\text { dependent mechanism } \\
\text { (up-regulation of p53- } \\
\text { dependent p21, Bax, } \\
\text { Fas) }\end{array}$ & $\begin{array}{l}\text { Naloxone increased the } \\
\text { growth-inhibitory } \\
\text { effects of morphine }\end{array}$ & $\begin{array}{l}\text { Tegeder et } \\
\text { al. } 2003\end{array}$ \\
\hline $\begin{array}{l}\text { EL-4 leukemia in } \\
\text { C57B16 mice, } \\
\text { sarcoma } 180 \text { in } \\
\text { ddY mice }\end{array}$ & $\begin{array}{l}\text { Increase of tumor } \\
\text { growth }\end{array}$ & $\begin{array}{l}10 \mathrm{mg} / \mathrm{kg} / \text { day s.c. for } \\
10 \text { days }\end{array}$ & $\begin{array}{l}\text { General } \\
\text { immunosuppressive } \\
\text { effect }\end{array}$ & $\begin{array}{l}\text { Naloxone itself had no } \\
\text { significant effect. The } \\
\text { effect was inhibited } \\
\text { by preadministration } \\
\text { of naloxone }\end{array}$ & $\begin{array}{l}\text { Ishikawa et } \\
\text { al. } 1993\end{array}$ \\
\hline $\begin{array}{l}\text { Walker } 256 \\
\text { carcinosarcoma } \\
\text { cells injected i. } \\
\text { v. in Sprague-- } \\
\text { Dawley rat }\end{array}$ & $\begin{array}{l}\text { Increase of the number } \\
\text { metastases }\end{array}$ & $5 \mathrm{mg} / \mathrm{kg}$ single dose & Suppresion of NK cells & $\begin{array}{l}\text { Naloxone itself had no } \\
\text { significant influence } \\
\text { on the number of } \\
\text { metastases. The effect } \\
\text { was inhibited by } \\
\text { preadministration of } \\
\text { naloxone }\end{array}$ & $\begin{array}{l}\text { Simon and } \\
\text { Arbo } \\
1986\end{array}$ \\
\hline $\begin{array}{l}\text { B16-BL6 } \\
\text { melanoma cells } \\
\text { injected into } \\
\text { hindpaw in } \\
\text { C57B1 mice }\end{array}$ & $\begin{array}{l}\text { Inhibition of tumor } \\
\text { growth and metastasis } \\
\text { (decreased number of } \\
\text { tumor nodules in the } \\
\text { lung) }\end{array}$ & $\begin{array}{l}5 \text { and } 10 \mathrm{mg} / \mathrm{kg} / \text { day s.c. } \\
\text { for } 6 \text { days, starting } \\
16 \text { days after cancer } \\
\text { cells injection }\end{array}$ & $\begin{array}{l}\text { Pain reduction and } \\
\text { blockade of pain } \\
\text { signals }\end{array}$ & & $\begin{array}{l}\text { Sasamura } \\
\text { et al. } \\
2002\end{array}$ \\
\hline $\begin{array}{l}\text { Colon 26-L5 car- } \\
\text { cinoma cells } \\
\text { injected i.v. in } \\
\text { BALB/c mice }\end{array}$ & $\begin{array}{l}\text { Inhibition of tumor } \\
\text { metastasis (reduction of } \\
\text { the number of tumor } \\
\text { colonies in the lung) }\end{array}$ & $\begin{array}{l}10 \mathrm{mg} / \mathrm{kg} / \text { day i.p. for } \\
6 \text { days, starting on day } \\
2 \text { after i.v. inoculation } \\
\text { of tumor cells }\end{array}$ & $\begin{array}{l}\text { Inhibition of adhesion and } \\
\text { invasion of cancer cells } \\
\text { (inhibition of MMP-2 } \\
\text { and } 9 \text { production) }\end{array}$ & & $\begin{array}{l}\text { Harimaya } \\
\text { et al. } \\
2002\end{array}$ \\
\hline $\begin{array}{l}\text { MCF-7 cells } \\
\text { injected into } \\
\text { the mammary } \\
\text { fat pad of nude } \\
\text { mice }\end{array}$ & $\begin{array}{l}\text { Increase of tumor } \\
\text { growth associated } \\
\text { with increased } \\
\text { angiogenesis } \\
\text { (neovascularization, } \\
\text { increased microvessel } \\
\text { density, higher vessel } \\
\text { number, increased } \\
\text { total length, and more } \\
\text { vessel branching) }\end{array}$ & $\begin{array}{l}0.714 \mathrm{mg} / \mathrm{kg} \text { mouse/day } \\
\text { for first } 15 \mathrm{days} \text { and } \\
\text { then } 1.43 \mathrm{mg} / \mathrm{kg} \\
\text { mouse } / \text { day (equivalent } \\
\text { to } 50 \mathrm{mg} \text { and } 100 \mathrm{mg} \\
\text { morphine per day, } \\
\text { respectively, for a } \\
70 \mathrm{~kg} \text { human) }\end{array}$ & $\begin{array}{l}\text { Activation of PI3K/Akt } \\
\text { and Erk pathways, } \\
\text { resulting in inhibition } \\
\text { of apoptosis and } \\
\text { promotion of cell cycle } \\
\text { progression }\end{array}$ & $\begin{array}{l}\text { Naloxone itself had no } \\
\text { significant effect on } \\
\text { angiogenesis. The } \\
\text { anti-angiogenic effect } \\
\text { of morphine was not } \\
\text { inhibited by naloxone }\end{array}$ & $\begin{array}{l}\text { Gupta et al. } \\
2002\end{array}$ \\
\hline $\begin{array}{l}\text { MADB-100 } \\
\text { mammary } \\
\text { adenocarcinoma } \\
\text { cells injected i.v. } \\
\text { in Fisher } 344 \\
\text { rats, } 5 \text { h after } \\
\text { surgery }\end{array}$ & $\begin{array}{l}\text { Inhibition of surgery- } \\
\text { induced increase in } \\
\text { metastasis }\end{array}$ & $\begin{array}{l}5 \mathrm{mg} / \mathrm{kg} 3 \text { doses (pre, } \\
\text { post and } 5 \mathrm{~h} \text { post } \\
\text { surgery) }\end{array}$ & $\begin{array}{l}\text { Inhibition of } \\
\text { postoperative pain } \\
\text { and stress-induced } \\
\text { immunosuppression }\end{array}$ & & $\begin{array}{l}\text { Page et al. } \\
1993\end{array}$ \\
\hline $\begin{array}{l}\text { Murine CCL-11 } \\
\text { sarcoma cells } \\
\text { injected into } \\
\text { femur of the } \\
\text { right leg in } \mathrm{C} 3 \mathrm{H} / \\
\text { HeJ mice }\end{array}$ & $\begin{array}{l}\text { Morphine did not } \\
\text { alter tumor burden }\end{array}$ & $\begin{array}{l}50,25,7.5,2.5 \mathrm{mg} / \mathrm{ml} \\
\text { implanted (s.c.) for } \\
7 \text { days following } \\
\text { injection of CCL-11 } \\
\text { cells into the femur }\end{array}$ & & & $\begin{array}{l}\text { King et al. } \\
2007\end{array}$ \\
\hline
\end{tabular}


Table 1 (continued)

\begin{tabular}{|c|c|c|c|c|c|}
\hline $\begin{array}{l}\text { Cell line/tumor } \\
\text { type }\end{array}$ & In vivo effects & In vivo dose/time & Suggested mechanism & Antagonist/inhibition & Ref. \\
\hline $\begin{array}{l}\text { Lewis lung } \\
\text { carcinoma cells } \\
\text { injected s.c. in } \\
\text { nude mice }\end{array}$ & $\begin{array}{l}\text { Reduction of tumor cell- } \\
\text { induced angiogenesis } \\
\text { and tumor growth }\end{array}$ & $\begin{array}{l}\text { A continuous slow- } \\
\text { release morphine pellet } \\
\text { resulting in morphine } \\
\text { plasma levels within } \\
250-400 \mathrm{ng} / \mathrm{ml}\end{array}$ & $\begin{array}{l}\text { Suppression of the } \\
\text { hypoxia-induced mito- } \\
\text { chondrial p38 } \\
\text { mitogen-activated pro- } \\
\text { tein kinase (MAPK) } \\
\text { pathway }\end{array}$ & $\begin{array}{l}\text { The effect was } \\
\text { abolished with } \\
\text { naltrexone }\end{array}$ & $\begin{array}{r}\text { Koodie et } \\
\text { al. } 2010\end{array}$ \\
\hline $\begin{array}{l}\text { TC-1 cells } \\
\text { injected s.c. } \\
\text { into the right } \\
\text { leg of C57BL/ } \\
6 \mathrm{~J} \text { mice }\end{array}$ & $\begin{array}{l}\text { Dose-dependent } \\
\text { increase of tumor } \\
\text { growth }\end{array}$ & $\begin{array}{l}10 \mathrm{mg} / \mathrm{kg} \text { i.p., twice } \\
\text { daily from day } 10 \\
\text { before tumor injection }\end{array}$ & $\begin{array}{l}\text { Immunosuppression } \\
\text { ( } \mu \text {-opioid receptor } \\
\text { mediated suppression } \\
\text { of T lymphocytes } \\
\text { proliferation, } \\
\text { promotion of apoptosis } \\
\text { of T lymphocytes } \\
\text { through Bcl-2 and Bax } \\
\text { apoptosis-related } \\
\text { molecules) }\end{array}$ & & $\begin{array}{l}\text { Cheng et } \\
\text { al. } 2006\end{array}$ \\
\hline
\end{tabular}

2007). However, significant differences between cell lines were found. For example, morphine produced a higher number of necrotic cells in the MCF-7 breast cancer cell line than in the A549 lung cancer cell line (Hatsukari et al. 2007).

Consistent with some previous studies (Tegeder et al. 2003), it was recently demonstrated that chronic high-dose morphine treatment was able to cause apoptotic cell death of SH-SY5Y cells in an opioid receptor-independent manner (Lin et al. 2009). A pivotal role in this process was played by c-Jun N-terminal kinase (JNK). Activation of JNK by morphine led to reactive oxygen species (ROS) generation and induced cytochrome c release and caspase$9 / 3$ activation through enhancement of expression of the pro-apoptotic protein Bim and reduction of expression of the anti-apoptotic protein Bcl-2. All of these effects of morphine could be suppressed by the JNK inhibitor. The key role of the JNK pathway in morphine-induced mitochondria-dependent apoptosis was further confirmed by the observation that decreased levels of JNK in cells transfected with specific small interfering RNA resulted in resistance to the pro-apoptotic effect of morphine.

It can be concluded that morphine can induce apoptosis and inhibit the growth of cancer cells by activating different signal pathways. Apart from the mitochondrial pathway mentioned above, apoptosis of MCF-7 cells was shown to be mediated by a novel sigma-2 receptor and p53 and caspase-independent pathway (Crawford et al. 2002; Crawford and Bowen 2002). CNE2 human epithelial tumor cell line was reported to undergo apoptosis by the activation of the K-opioid receptor via the phospholipase pathway (Diao et al. 2000).

The growth-inhibitory or apoptosis-inducing effects of morphine might be directly associated with morphine tolerance (Wu et al. 1999; Mao et al. 2002) or receptor desensitization, as assessed by a lack of morphine- stimulated GTP-ase activity at concentrations that inhibit tumor growth (Tegeder et al. 2003). Drugs that prevented the development of morphine tolerance in rats also prevented cell death (Mao et al. 2002). This close association between apoptosis and receptor desensitization suggests that receptor internalization may be the key event in initiating opioid-evoked cell death.

On the other hand, evidence of the anti-apoptotic activity of morphine is also accumulating (Suzuki et al. 2003). It was shown that morphine can antagonize the pro-apoptotic activity of a well-known anti-tumor drug, doxorubicin, in neuroblastoma SH-SY5Y cells (Lin et al. 2007). The effect could not be reversed by naloxone, indicating a non-opioid receptor-mediated signaling pathway. Further studies showed that morphine attenuated doxorubicin-induced apoptosis by the inhibition of ROS generation and mitochondrial cytochrom c release, as well as by blockade of nuclear factor $\mathrm{kB}(\mathrm{NF}-\mathrm{kB})$ transcriptional activation. $\mathrm{NF}-\mathrm{kB}$ is a ubiquitous nuclear transcription factor that plays a major regulatory role in apoptosis and inflammation. Iglesias et al. (2003) demonstrated that in SH-SY5Y neuroblastoma cells, morphine $\left(10^{-7}-10^{-5} \mathrm{M}\right)$ promoted cell survival after serum deprivation without inducing cell proliferation, and this effect was fully reversed by naloxone. It was shown that in neuronal cells, $\mu$-opioid agonists do not directly induce apoptosis, but are able to activate the phosphatidylinositol 3-kinase/Akt (PI3K/Akt) signal transduction pathway, thus leading to cell survival.

\section{Effect of morphine on angiogenesis}

Successful tumor growth depends on many aspects, of which the most important are proliferation of tumor cells and angiogenesis or the formation of new blood vessels which 
are necessary for metastasis (Carmeliet and Jain 2000). To date, very few studies have investigated the effect of morphine on tumor cell-induced angiogenesis. Gupta et al. (2002) showed that at clinically relevant concentrations, morphine stimulated human microvascular endothelial cell proliferation and angiogenesis in vitro, and that in vivo these effects translated into enhanced tumor neovascularization in the MCF-7 breast cancer model. In addition, this group demonstrated that morphine promoted activation of vascular endothelial growth factor (VEGF) receptor and increased metastasis and reduced survival in animal model of hormone-dependent breast cancer (Chen et al. 2006; Farooqui et al. 2007). However, the opioid receptor antagonist, naloxone, did not inhibit the proangiogenic activity of morphine, indicating that the effect was not mediated by the typical opioid receptors.

On the other hand, Singleton and Moss (2010) demonstrated that $\mu$-opioids (morphine) transactivate the VEGF receptors and promote angiogenesis. The $\mu$-opioid receptor antagonist methylnaltrexone blocks opioid-induced angiogenesis in cultured human endothelial cells.

It was postulated that the pro-angiogenic activity of morphine is connected with the stimulation of mitogenactivated protein kinase (MAPK) signaling pathway via $G$ protein-coupled receptors and nitric oxide (NO). Chronic morphine treatment increased the levels of nitric oxide synthase (NOS), NO, and cyclooxygenase-2 (COX-2) in mouse kidney (Stefano et al. 1995; Arerangaiah et al. 2007). NO stimulated the enzymatic activity of COX-2 (Salvemini et al. 1993), and activated COX-2 in turn increased prostaglandin $\mathrm{E}_{2}$ production (Salvemini et al. 1993, 1994; Nedelec et al. 2001; Birnbaum et al. 2005). Prostaglandin $E_{2}$ promoted angiogenesis and tumor progression (Griffin et al. 2002; Leahy et al. 2002; Chang et al. 2004). The role of COX-2 in cancer progression was further studied by Farooqui et al. (2007). Two weeks of chronic morphine treatment of experimental mice with highly invasive SCK breast cancer model stimulated COX-2, prostaglandin $E_{2}$, and angiogenesis, which was accompanied by increased tumor weight, increased metastasis, and reduced survival. It was postulated that products of COX-2, such as prostaglandin $\mathrm{E}_{2}$ produced in tumor cells, act on the tumor endothelium and promote angiogenesis. Notably, morphine induced a much stronger expression of COX-2 in tumor cells than in endothelial cells. Co-administration of COX-2 inhibitor, celecoxib, prevented morphine-induced promotion of angiogenesis and tumor growth. Therefore, morphineinduced tumor growth may in part be due to the upregulation of COX-2 and prostaglandin $\mathrm{E}_{2}$-mediated stimulation of angiogenesis. It was also shown that morphine did not have any effect on MCF-7 human breast cancer cell proliferation in vitro (Farooqui et al. 2006) but stimulated MCF-7 breast tumor growth by promoting angiogenesis (Gupta et al. 2002). That means that morphine by itself did not modulate tumor cell growth in culture, but due to upregulation of COX-2 in tumor cells, stimulated angiogenesis in vivo, resulting in increased tumor growth and metastasis. The pro-angiogenic activity of morphine was also reported by Ustun et al. (2010).

Contradictory data on the effect of morphine on angiogenesis were also published. It is well known that when the solid tumor grows, new tumor cells are localized further away from their vascular supply, and low oxygen tensions or hypoxia stimulate tumor cells to secrete proangiogenic factors (Folkman and D'Amore 1996). A potent pro-angiogenic factor secreted by hypoxic tumor cells within developing solid tumor is vascular endothelial growth factor (VEGF). This factor promotes new blood vessel formation to sustain tumor growth and initiates endothelial cell proliferation and migration (Brekken and Thorpe 2001; Ferrara 2004). Balasubramanian et al. (2001) reported that morphine inhibited hypoxia-induced VEGF secretion in rat cardiomyocytes and human umbilical vein endothelial cells and therefore attenuated the ability of hypoxic tumor cells to induce angiogenesis. Most recently, the same effect was observed in a murine Lewis lung carcinoma tumor model (Koodie et al. 2010). Morphine was administered to mice at the clinically relevant analgesic doses by implantation of continuous slow-release pallets. Morphine plasma level within $250-400 \mathrm{ng} / \mathrm{mL}$ was sufficient to significantly reduce tumor cell-induced angiogenesis and tumor growth. The effect of morphine was abolished by concomitant administration of opioid antagonist, naltrexone, and also in the $\mu$ opioid receptor knockout mice, supporting the involvement of classical opioid receptors in the process. The authors also demonstrated that the inhibitory effect of morphine was mediated through the suppression of the hypoxia-induced mitochondrial p38 MAPK pathway.

Much earlier, it was shown that high concentrations of morphine $(10 \mathrm{mg} / \mathrm{mL}$ of plasma $)$ inhibited angiogenesis in the chick chorioallantoic membrane assay (Pasi et al. 1991). However, morphine is cytotoxic to endothelial cells at such high concentrations (Gupta et al. 2002), so the observed effect could have been non-specific. In wound healing experiments in mice, systemic administration of high-dose morphine resulted in impared mobilization of endothelial progenitor cells and angiogenesis, delaying the healing process. Consistent with the in vivo experiment, in cultured endothelial cells, morphine reduced capillary tube formation in a concentration-dependent manner (Lam et al. 2008).

\section{Effect of morphine on migration and invasiveness of tumor cells}

A major feature of cancer cells is their ability to migrate and settle in surrounding or distant tissues. Most cancer 
deaths and the main cause of failure in cancer treatment is not due to growth of the primary tumor but results from its intensive spread (metastasis) to secondary sites (Engbring and Kleinman 2003; Widel and Widel 2006). The critical step of cancer dissemination is migration of cancer cells through the extracellular matrix (ECM). Indispensable in this process is activation of urokinase plasminogen activator system, which includes a serine proteinase, urokinase plasminogen activator (uPA), two inhibitors, PAI-1 and PAI-2, and the membranelinked receptor (UPAR) (Duffy and Duggan 2004), plasmin and matrix metalloproteinases (MMPs) (Mignatti and Rifkin 2000) capable of degrading the ECM.

It was shown that UPA, PAI-1, and UPAR levels are upregulated in most types of cancers (Shapiro et al. 1996). The effect of morphine on uPA levels was studied in vitro by several authors. Gach et al. (2009) showed that morphine caused a markedly increased secretion of UPA in MCF-7 breast cancer cells, which correlated well with upregulation of uPA and UPAR mRNA levels. Naloxone reversed morphine-induced up-regulation of UPA and UPA mRNA levels confirming the involvement of the opioid receptors in this process. A similar result was reported by Nylund et al. (2008) who demonstrated that morphine stimulated uPA secretion in HT-29 colon cancer cells.

The MMPs constitute a family of zinc-dependent endopeptidases, whose primary function is remodeling of components in the ECM (Engbring and Kleinman 2003; Widel and Widel 2006; Jespersen et al. 2009). Among the different MMPs involved in degradation of ECM in cancer cells, it seems that MMP-2 (gelatinase A) and MMP-9 (gelatinase B) play a crucial role in cancer invasion because of their ability to degrade type IV collagen, a major component of basement membranes (Widel and Widel 2006). The activity of MMPs is strictly regulated at the transcription and translation levels by endogenous inhibitors, including $\alpha 2$-macroglobulin and tissue inhibitors of metalloproteinases (TIMPs). Several studies have shown that MMP expression and activity were increased in several tumor types, especially breast and lung cancer. The up-regulated levels of MMPs correlated well with tumor stage, increased invasion, and potential metastasis (Lynch and Matrisian 2002; Widel and Widel 2006). Morphine was found to significantly reduce experimental lung metastasis and invasion of colon 26-L5 cells by inhibiting adhesion and migration of these cells to ECM (Harimaya et al. 2002). In the mouse fibrosarcoma cell line, WEHI 164, activity of MMP-2 was shown to be under control of NO system and was attenuated by low doses of morphine in a non-opioid receptor-related manner (Shariftabrizi et al. 2006). In the MCF-7 cell line, morphine inhibited expression and secretion of MMP-2 and -9 in time- and concentrationdependent manner, and the process was not mediated by opioid receptors but was also under the control of the NO system (Gach et al. 2011).

\section{Effect of morphine on immune system}

Disorders in the immune system can result in disease, including inflammatory diseases and cancer. Morphine mediates its analgesic effect by the $\mu$-opioid receptor. The expression of the $\mu$-opioid receptor gene in neuronal cells is regulated by cytokines, released from the cells of the immune system. On the other hand, $\mu$-opioid receptor is also expressed in the cells of immune system, such as lymphocytes and macrophages (Börner et al. 2007). This points at the importance of interactions between opioid and immune system (Kraus 2009). The fact that morphine can inhibit numerous immune cell functions and cause immunosuppression is well known (Peterson et al. 1993; Sacerdote et al. 1997; Eisenstein and Hilburger 1998). In particular, morphine decreases the activity of natural killer cells which play a major role in the rejection of tumors (Sacerdote et al. 1997) and increases the susceptibility of animals and humans to bacterial and viral infections (Yeager et al. 1995; Risdahl et al. 1998; MacFarlane et al. 2000). It was also shown that morphine inhibits production of pro-inflammatory cytokines (e.g., TNF, IL-6) in monocytes (Bonnet et al. 2008), modulates the $\mathrm{T}$ helper cell balance by inducing up-regulation of an anti-inflammatory IL-4 mRNA (Roy et al. 2005) and produces immunosuppression by inhibition of transcription of IL-2 in activated lymphocytes T (Börner et al. 2009). However, future research is necessary to provide clearer understanding of the cellular and molecular targets of morphine action within the immune system.

\section{Conclusions}

For more than two decades, researchers have been trying to document the effects that morphine exerts on tumor cells. It has been recognized that morphine can affect tumor growth by either directly acting on the tumor cells or by directly acting on the endothelial cells or on the CNS-mediated secretion of growth factors that may alter tumor microenvironment. Suppression of immune system by morphine can be an additional complication. However, the results obtained both in in vitro and in vivo studies are conflicting. On one hand, morphine was shown to induce tumor growth, inhibit apoptosis, promote angiogenesis and migration of tumor cells, but on the other hand, pro-apoptotic and antiangiogenic properties of morphine were also demonstrated. Performed studies were very heterogenic due to the different doses of morphine applied, and the effects may vary when the experiments were performed in vivo or on isolated cells. The dose and route of administration of morphine might be critical factors that need to be taken into consideration in clinical settings. Contradictory results that 
have been obtained induce further studies. The final answer to the question whether morphine is an inhibitor of tumor growth or whether it promotes cancer is still to be sought. The effects of morphine can also depend on a cancer type, since different cancer cells can overexpress certain enzymes which are possible morphine targets.

Acknowledgements This work was supported by the grants from the Medical University of Lodz (No 503/1-156-02/503-01, from Polish Ministry of Science "Iuventus Plus" (No IP2010009470 for K. G.) and 'START' scholarship of the Foundation for Polish Science (for K.G.).

Open Access This article is distributed under the terms of the Creative Commons Attribution Noncommercial License which permits any noncommercial use, distribution, and reproduction in any medium, provided the original author(s) and source are credited.

\section{References}

Arerangaiah R, Chalasani N, Udager AM, Weber ML, Manivel JC, Griffin RJ, Song CW, Gupta K (2007) Opioids induce renal abnormalities in tumor-bearing mice. Nephron Exp Nephrol 105:e80-e89

Ashkenazi A, Dixit VM (1999) Apoptosis control by death and decoy receptors. Curr Opin Cell Biol 11:255-260

Balasubramanian S, Ramakrishnan S, Charboneau R, Wang J, Barke RA, Roy S (2001) Morphine sulfate inhibits hypoxia-induced vascular endothelial growth factor expression in endothelial cells and cardiac myocytes. J Mol Cell Cardiol 33:2179-2187

Birnbaum Y, Ye Y, Rosanio S, Tavackoli S, Hu ZY, Schwarz ER, Uretsky BF (2005) Prostaglandins mediate the cardioprotective effects of atorvastatin against ischemia-reperfusion injury. Cardiovasc Res 65:345-355

Bonnet MP, Beloeil H, Benhamou D, Mazoit JX, Asehnoune K (2008) The mu opioid receptor mediates morphine-induced tumor necrosis factor and interleukin-6 inhibition in toll-like receptor 2-stimulated monocytes. Anesth Analg 106:1142-1149

Börner C, Stumm R, Hollt V, Kraus J (2007) Comparative analysis of mu-opioid receptor expression in immune and neuronal cells. $\mathrm{J}$ Neuroimmunol 188:56-63

Börner C, Warnick B, Smida M, Hartig R, Lindquist JA, Schraven B, Höllt V, Kraus J (2009) Mechanisms of opioid-mediated inhibition of human $\mathrm{T}$ cell receptor signaling. J Immunol 183:882-889

Brekken RA, Thorpe PE (2001) Vascular endothelial growth factor and vascular targeting of solid tumors. Anticancer Res 21:4221-4229

Carmeliet P, Jain RK (2000) Angiogenesis in cancer and other diseases. Nature 407:249-257

Chang SH, Liu CH, Conway R, Han DK, Nithipatikom K, Trifan OC, Lane TF, Hla $T$ (2004) Role of prostaglandin E2-dependent angiogenic switch in cyclooxygenase 2-induced breast cancer progression. Proc Natl Acad Sci USA 101:591-596

Chen C, Farooqui M, Gupta K (2006) Morphine stimulates vascular endothelial growth factor-like signaling in mouse retinal endothelial cells. Curr Neurovasc Res 3:171-180

Chen YL, Law PY, Loh HH (2008) The other side of the opioid story: modulation of cell growth and survival signaling. Curr Med Chem 15:772-778

Cheng WF, Chen LK, Chen CA, Chang MC, Hsiao PN, Su YN, Lee CN, Jeng HJ, Hsieh CY, Sun WZ (2006) Chimeric DNAvaccine reverses morphine-induced immunosuppression and tumorigenesis. Mol Ther 13:203-210
Cory S, Adams JM (2002) The Bcl2 family: regulators of the cellular life-or-death switch. Nat Rev Cancer 2:647-656

Cory S, Huang DC, Adams JM (2003) The Bcl-2 family: roles in cell survival and oncogenesis. Oncogene 22:8590-8607

Crawford KW, Bowen WD (2002) Sigma-2 receptor agonists activate a novel apoptotic pathway and potentiate antineoplastic drugs in breast tumor cell lines. Cancer Res 62:313-322

Crawford KW, Coop A, Bowen WD (2002) Sigma(2) receptors regulate changes in sphingolipid levels in breast tumor cells. Eur J Pharmacol 443:207-209

Diao CT, Li L, Lau SY, Wong TM, Wong NS (2000) Kappa-opioid receptor potentiates apoptosis via a phospholipase $\mathrm{C}$ pathway in the CNE2 human epithelial tumor cell line. Biochim Biophys Acta 1499:49-62

Duffy MJ, Duggan C (2004) The urokinase plasminogen activator system: a rich source of tumour markers for the individualised management of patients with cancer. Clin Biochem 37:541-548

Eisenstein TK, Hilburger ME (1998) Opioid modulation of immune responses: effects on phagocyte and lymphoid cell populations. J Neuroimmunol 83:36-44

Engbring JA, Kleinman HK (2003) The basement membrane matrix in malignancy. J Pathol 200:465-470

Farooqui M, Geng ZH, Stephenson EJ, Zaveri N, Yee D, Gupta K (2006) Naloxone acts as an antagonist of estrogen receptor activity in MCF-7 cells. Mol Cancer Ther 5:611-620

Farooqui M, Li Y, Rogers T, Poonawala T, Griffin RJ, Song CW, Gupta K (2007) COX-2 inhibitor celecoxib prevents chronic morphineinduced promotion of angiogenesis, tumour growth, metastasis and mortality, without compromising analgesia. $\mathrm{Br} \mathrm{J}$ Cancer 97:1523-1531

Ferrara N (2004) Vascular endothelial growth factor: basic science and clinical progress. Endocr Rev 25:581-611

Fichna J, Janecka A (2004) Opioid peptides in cancer. Cancer Metastasis Rev 23:351-366

Folkman J, D'Amore PA (1996) Blood vessel formation: what is its molecular basis? Cell 87:1153-1155

Fulda S, Debatin KM (2006) Modulation of apoptosis signaling for cancer therapy. Arch Immunol Ther Exp (Warsz) 54:173-175

Gach K, Szemraj J, Fichna J, Piestrzeniewicz M, Delbro DS, Janecka A (2009) The influence of opioids on urokinase plasminogen activator on protein and mRNA level in MCF-7 breast cancer cell line. Chem Biol Drug Des 74:390-396

Gach K, Szemraj J, Wyrebska A, Janecka A (2011) The influence of opioids on matrix metalloproteinase- 2 and -9 secretion and mRNA levels in MCF-7 breast cancer cell line. Mol Biol Rep 38:1231-1236

Green DR, Reed JC (1998) Mitochondria and apoptosis. Science 281:1309-1312

Griffin RJ, Williams BW, Wild R, Cherrington JM, Park H, Song CW (2002) Simultaneous inhibition of the receptor kinase activity of vascular endothelial, fibroblast, and platelet-derived growth factors suppresses tumor growth and enhances tumor radiation response. Cancer Res 62:1702-1706

Gupta K, Kshirsagar S, Chang L, Schwartz R, Law PY, Yee D, Hebbel RP (2002) Morphine stimulates angiogenesis by activating proangiogenic and survival-promoting signaling and promotes breast tumor growth. Cancer Res 62:4491-4498

Hanahan D, Weinberg RA (2000) The hallmarks of cancer. Cell 100:57-70

Harimaya Y, Koizumi K, Andoh T, Nojima H, Kuraishi Y, Saiki I (2002) Potential ability of morphine to inhibit the adhesion, invasion and metastasis of metastatic colon 26-L5 carcinoma cells. Cancer Lett 187:121-127

Harrison LM, Kastin AJ, Zadina JE (1998) Opiate tolerance and dependence: receptors, G-proteins, and antiopiates. Peptides 19:1603-1630 
Hatsukari I, Hitosugi N, Matsumoto I, Nagasaka H, Sakagami H (2003) Induction of early apoptosis marker by morphine in human lung and breast carcinoma cell lines. Anticancer Res 23:2413-2417

Hatsukari I, Hitosugi N, Ohno R, Hashimoto K, Nakamura S, Satoh K, Nagasaka H, Matsumoto I, Sakagami H (2007) Induction of apoptosis by morphine in human tumor cell lines in vitro. Anticancer Res 27:857-864

Hatzoglou A, Bakogeorgou E, Castanas E (1996) The antiproliferative effect of opioid receptor agonists on the T47D human breast cancer cell line, is partially mediated through opioid receptors. Eur J Pharmacol 296:199-207

Hengartner MO (2000) The biochemistry of apoptosis. Nature 407:770-776

Hsiao PN, Chang MC, Cheng WF, Chen CA, Lin HW, Hsieh CY, Sun WZ (2009) Morphine induces apoptosis of human endothelial cells through nitric oxide and reactive oxygen species pathways. Toxicology 256:83-91

Iglesias M, Segura MF, Comella JX, Olmos G (2003) Mu-opioid receptor activation prevents apoptosis following serum withdrawal in differentiated SH-SY5Y cells and cortical neurons via phosphatidylinositol 3-kinase. Neuropharmacology 44(4):482492

Ishikawa M, Tanno K, Kamo A, Takayanagi Y, Sasaki K (1993) Enhancement of tumor growth by morphine and its possible mechanism in mice. Biol Pharm Bull 16:762-766

Janecka A, Fichna J, Kosson P, Zalewska-Kaszubska J, Krajewska U, Mirowski M, Rozalski M (2004) Binding of the new morphiceptin analogs to human MCF-7 breast cancer cells and their effect on growth. Regul Pept 120:237-241

Jespersen C, Doller A, Akool e, Bachmann M, Muller R, Gutwein P, Muhl H, Pfeilschifter J, Eberhardt W (2009) Molecular mechanisms of nitric oxide-dependent inhibition of TPA-induced matrix metalloproteinase-9 (MMP-9) in MCF-7 cells. J Cell Physiol 219:276-287

Kapasi AA, Coscia SA, Pandya MP, Singhal PC (2004) Morphine modulates HIV-1 gp160-induced murine macrophage and human monocyte apoptosis by disparate ways. J Neuroimmunol 148:86-96

Kaufmann SH, Hengartner MO (2001) Programmed cell death: alive and well in the new millennium. Trends Cell Biol 11:526-534

Kawase M, Sakagami H, Furuya K, Kikuchi H, Nishikawa H, Motohashi N, Morimoto Y, Varga A, Molnar J (2002) Cell death-inducing activity of opiates in human oral tumor cell lines. Anticancer Res 22:211-214

Kieffer BL (1999) Opioids: first lessons from knockout mice. Trends Pharmacol Sci 20:19-26

Kieffer BL, Gaveriaux-Ruff C (2002) Exploring the opioid system by gene knockout. Prog Neurobiol 66:285-306

King T, Vardanyan A, Majuta L, Melemedjian O, Nagle R, Cress AE, Vanderah TW, Lai J, Porreca F (2007) Morphine treatment accelerates sarcoma-induced bone pain, bone loss, and spontaneous fracture in a murine model of bone cancer. Pain 132:154 168

Koodie L, Ramakrishnan S, Roy S (2010) Morphine suppresses tumor angiogenesis through a HIF-1alpha/p38MAPK pathway. Am J Pathol 177:984-997

Kraus J (2009) Regulation of mu-opioid receptors by cytokines. Front Biosci 1:164-170, Schol. Ed

Lam CF, Chang PJ, Huang YS, Sung YH, Huang CC, Lin MW, Liu YC, Tsai YC (2008) Prolonged use of high-dose morphine impairs angiogenesis and mobilization of endothelial progenitor cells in mice. Anesth Analg 107:686-692

Lazarczyk M, Matyja E, Lipkowski AW (2010) A comparative study of morphine stimulation and biphalin inhibition of human glioblastoma T98G cell proliferation in vitro. Peptides 31:16061612
Leahy KM, Ornberg RL, Wang Y, Zweifel BS, Koki AT, Masferrer JL (2002) Cyclooxygenase-2 inhibition by celecoxib reduces proliferation and induces apoptosis in angiogenic endothelial cells in vivo. Cancer Res 62:625-631

Lin X, Li Q, Wang YJ, Ju YW, Chi ZQ, Wang MW, Liu JG (2007) Morphine inhibits doxorubicin-induced reactive oxygen species generation and nuclear factor kappaB transcriptional activation in neuroblastoma SH-SY5Y cells. Biochem J 406:215-221

Lin X, Wang YJ, Li Q, Hou YY, Hong MH, Cao YL, Chi ZQ, Liu JG (2009) Chronic high-dose morphine treatment promotes SHSY5Y cell apoptosis via c-Jun N-terminal kinase-mediated activation of mitochondria-dependent pathway. FEBS J 276:2022-2036

Lynch CC, Matrisian LM (2002) Matrix metalloproteinases in tumorhost cell communication. Differentiation 70:561-573

MacFarlane AS, Peng X, Meissler JJ Jr, Rogers TJ, Geller EB, Adler MW, Eisenstein TK (2000) Morphine increases susceptibility to oral Salmonella typhimurium infection. J Infect Dis 181:1350 1358

Maneckjee R, Biswas R, Vonderhaar BK (1990) Binding of opioids to human MCF-7 breast cancer cells and their effects on growth. Cancer Res 50:2234-2238

Mantyh PW (2006) Cancer pain and its impact on diagnosis, survival and quality of life. Nat Rev Neurosci 7:797-809

Mao J, Sung B, Ji RR, Lim G (2002) Neuronal apoptosis associated with morphine tolerance: evidence for an opioid-induced neurotoxic mechanism. J Neurosci 22:7650-7661

Mathew B, Lennon F, Siegler J, Gerhold L, Mambetsariev N, MorenoVinasco L, Garcia J, Salgia R, Moss J, Singleton P (2009) The mu-opioid receptor regulates Lewis lung carcinoma tumor growth and metastasis. Mol Cancer Ther 8:C78

Mignatti P, Rifkin DB (2000) Nonenzymatic interactions between proteinases and the cell surface: novel roles in normal and malignant cell physiology. Adv Cancer Res 78:103-157

Moon TD (1988) The effect of opiates upon prostatic carcinoma cell growth. Biochem Biophys Res Commun 153:722-727

Moss J, Rosow CE (2008) Development of peripheral opioid antagonists' new insights into opioid effects. Mayo Clin Proc 83:1116-1130

Nedelec E, Abid A, Cipolletta C, Presle N, Terlain B, Netter P, Jouzeau J (2001) Stimulation of cyclooxygenase-2-activity by nitric oxide-derived species in rat chondrocyte: lack of contribution to loss of cartilage anabolism. Biochem Pharmacol 61:965-978

Nylund G, Pettersson A, Bengtsson C, Khorram-Manesh A, Nordgren S, Delbro DS (2008) Functional expression of mu-opioid receptors in the human colon cancer cell line, HT-29, and their localization in human colon. Dig Dis Sci 53:461-466

Odunayo A, Dodam JR, Kerl ME, DeClue AE (2010) Immunomodulatory effects of opioids. J Vet Emerg Crit Care 20:376-385 (San. Antonio.)

Page GG, Ben-Eliyahu S, Yirmiya R, Liebeskind JC (1993) Morphine attenuates surgery-induced enhancement of metastatic colonization in rats. Pain 54:21-28

Pasi A, Qu BX, Steiner R, Senn HJ, Bar W, Messiha FS (1991) Angiogenesis: modulation with opioids. Gen Pharmacol 22:1077-1079

Pasternak GW (1993) Pharmacological mechanisms of opioid analgesics. Clin Neuropharmacol 16:1-18

Peterson PK, Molitor TW, Chao CC (1993) Mechanisms of morphineinduced immunomodulation. Biochem Pharmacol 46:343-348

Rasmussen M, Zhu W, Tonnesen J, Cadet P, Tonnesen E, Stefano GB (2002) Effects of morphine on tumour growth. Neuro Endocrinol Lett 23:193-198

Reisine T, Bell GI (1993) Molecular biology of opioid receptors. Trends Neurosci 16:506-510 
Risdahl JM, Khanna KV, Peterson PK, Molitor TW (1998) Opiates and infection. J Neuroimmunol 83:4-18

Roy S, Wang J, Charboneau R, Loh HH, Barke RA (2005) Morphine induces CD4+ T cell IL-4 expression through an adenylyl cyclase mechanism independent of the protein kinase A pathway. J Immunol 175:6361-6367

Sacerdote P, Manfredi B, Mantegazza P, Panerai AE (1997) Antinociceptive and immunosuppressive effects of opiate drugs: a structure-related activity study. Br J Pharmacol 121:834-840

Salvemini D, Misko TP, Masferrer JL, Seibert K, Currie MG, Needleman P (1993) Nitric oxide activates cyclooxygenase enzymes. Proc Natl Acad Sci USA 90:7240-7244

Salvemini D, Seibert K, Masferrer JL, Misko TP, Currie MG, Needleman P (1994) Endogenous nitric oxide enhances prostaglandin production in a model of renal inflammation. J Clin Invest 93:1940-1947

Sartorius U, Schmitz I, Krammer PH (2001) Molecular mechanisms of death-receptor-mediated apoptosis. Chembiochem 2:20-29

Sasamura T, Nakamura S, Iida Y, Fujii H, Murata J, Saiki I, Nojima H, Kuraishi Y (2002) Morphine analgesia suppresses tumor growth and metastasis in a mouse model of cancer pain produced by orthotopic tumor inoculation. Eur J Pharmacol 441:185-191

Schmitz R (1985) Friedrich Wilhelm Serturner and the discovery of morphine. Pharm Hist 27:61-74

Shapiro RL, Duquette JG, Roses DF, Nunes I, Harris MN, Kamino H, Wilson EL, Rifkin DB (1996) Induction of primary cutaneous melanocytic neoplasms in urokinase-type plasminogen activator (uPA)-deficient and wild-type mice: cellular blue nevi invade but do not progress to malignant melanoma in uPA-deficient animals. Cancer Res 56:3597-3604

Shariftabrizi A, Nifli AP, Ansari M, Saadat F, Ebrahimkhani MR, Alizadeh N, Nasseh A, Alexaki VI, Dehpour AR, Castanas E, Khorramizadeh MR (2006) Matrix metalloproteinase 2 secretion in WEHI 164 fibrosarcoma cells is nitric oxide-related and modified by morphine. Eur J Pharmacol 530:33-39

Simon RH, Arbo TE (1986) Morphine increases metastatic tumor growth. Brain Res Bull 16:363-367

Singleton PA, Moss J (2010) Effect of perioperative opioids on cancer recurrence: a hypothesis. Future Oncol 6:1237-1242

Smith MT, Wright AW, Williams BE, Stuart G, Cramond T (1999) Cerebrospinal fluid and plasma concentrations of morphine, morphine-3-glucuronide, and morphine-6-glucuronide in patients before and after initiation of intracerebroventricular morphine for cancer pain management. Anesth Analg 88:109-116

Stefano GB, Hartman A, Bilfinger TV, Magazine HI, Liu Y, Casares F, Goligorsky MS (1995) Presence of the mu3 opiate receptor in endothelial cells. Coupling to nitric oxide production and vasodilation. J Biol Chem 270:30290-30293
Sueoka N, Sueoka E, Okabe S, Fujiki H (1996) Anti-cancer effects of morphine through inhibition of tumour necrosis factor-alpha release and mRNA expression. Carcinogenesis 17:2337-2341

Sueoka E, Sueoka N, Kai Y, Okabe S, Suganuma M, Kanematsu K, Yamamoto T, Fujiki H (1998) Anticancer activity of morphine and its synthetic derivative, KT-90, mediated through apoptosis and inhibition of NF-kappaB activation. Biochem Biophys Res Commun 252:566-570

Suzuki S, Chuang LF, Doi RH, Chuang RY (2003) Morphine suppresses lymphocyte apoptosis by blocking p53-mediated death signaling. Biochem Biophys Res Commun 308:802-808

Tegeder I, Geisslinger G (2004) Opioids as modulators of cell death and survival - unraveling mechanisms and revealing new indications. Pharmacol Rev 56:351-369

Tegeder I, Grosch S, Schmidtko A, Haussler A, Schmidt H, Niederberger E, Scholich K, Geisslinger G (2003) G protein-independent G1 cell cycle block and apoptosis with morphine in adenocarcinoma cells: involvement of p53 phosphorylation. Cancer Res 63:1846-1852

Ustun F, Durmus-Altun G, Altaner S, Tuncbilek N, Uzal C, Berkarda S (2010) Evaluation of morphine effect on tumour angiogenesis in mouse breast tumour model, EATC. Med. Oncol (in press)

Wang CZ, Li XL, Sun S, Xie JT, Aung HH, Tong R, McEntee E, Yuan CS (2009) Methylnaltrexone, a peripherally acting opioid receptor antagonist, enhances tumoricidal effects of $5-\mathrm{Fu}$ on human carcinoma cells. Anticancer Res 29:2927-2932

Widel MS, Widel M (2006) Mechanisms of metastasis and molecular markers of malignant tumor progression. I. Colorectal cancer. Postepy Hig Med Dosw (Online) 60:453-470

Wu WR, Zheng JW, Li N, Bai HQ, Zhang KR, Li Y (1999) Immunosuppressive effects of dihydroetorphine, a potent narcotic analgesic, in dihydroetorphine-dependent mice. Eur J Pharmacol 366:261-269

Yeager MP, Colacchio TA (1991) Effect of morphine on growth of metastatic colon cancer in vivo. Arch Surg 126:454-456

Yeager MP, Colacchio TA, Yu CT, Hildebrandt L, Howell AL, Weiss J, Guyre PM (1995) Morphine inhibits spontaneous and cytokineenhanced natural killer cell cytotoxicity in volunteers. Anesthesiology 83:500-508

Zadina JE, Kastin AJ, Ge LJ, Hackler L (1994) Mu, delta, and kappa opiate receptor binding of Tyr-MIF-1 and of Tyr-W-MIF-1, its active fragments, and two potent analogs. Life Sci 55:L461-L466

Zagon IS, Hytrek SD, Lang CM, Smith JP, McGarrity TJ, Wu Y, McLaughlin PJ (1996) Opioid growth factor ([Met5]enkephalin) prevents the incidence and retards the growth of human colon cancer. Am J Physiol 271:R780-R786

Zong J, Pollack GM (2000) Morphine antinociception is enhanced in mdr1a gene-deficient mice. Pharm Res 17:749-753 